\author{
MAGDALENA KRÓL \\ Uniwersytet Jagielloński, Wydział Filologiczny, Instytut Językoznawstwa, \\ Katedra Językoznawstwa Ogólnego i Indoeuropejskiego
}

\title{
Wartość w słowie czy wartość słowa, czyli jak rozmawiamy ze sobą na co dzień?
}

Problem zarysowany w niniejszym artykule nie będzie dotyczył ontycznego statusu słowa. Praca ta jest próbą połączenia teorii relacji językoznawstwa i aksjologii z przykładami pochodzącymi ze słownika gwary młodzieżowej ${ }^{1}$. Istniejący w dyskursie językoznawstwa i aksjologii problem relacji języka do wartości zostanie podparty przykładami skłaniającymi do opowiedzenia się za istnieniem wartości w rzeczywistości pozajęzykowej i asocjacyjnie wyrażanej przez językowe narzędzia. Wbrew sugestii, którą tytuł ten z sobą niesie, nie zostanie poruszona tu problematyka opisywanego przez stulecia sporu naturalistów czy też zwolenników filozofii physei z theseistami, lub też ich kontynuatorów w rozważaniu nad naturą języka - analogistów i anomalistów. Nie jest też głównym celem próba odpowiedzi sensu stricto na pytanie zawarte w tytule artykułu. To, nad czym próbowano się zastanowić, to kształtowanie się postrzegania wartości przez pryzmat słowa, a zwłaszcza sformułowań wykorzystujących frazy czy leksemy będące nośnikami nazw określających wartości i postawy. Poruszona zostanie tu również problematyka immanentnego wartościowania słów i konotacyjnego przypisywania im wartości.

Jakkolwiek przekaz wartości nie zawsze odbywa się na płaszczyźnie słownej, treść artykułu skoncentrowana jest wokół językowych form przekazu, czerpiąc z dorobku aksjologów - kognitywistów, którzy zakładają możliwość poznania

${ }^{1}$ Materiał do badań stanowią słowa zasłyszane w środowisku uczniów Zespołu Szkół Energetycznych w Krakowie podczas praktyki zawodowej, odbywanej przez autorkę. Zidentyfikowane słowa i zwroty zostały zweryfikowane w bazach, jakie stanowią Miejski słownik slangu i mowy potocznej i Stownik slangu, neologizmów i mowy potocznej. Analizie poddawane zostały tylko te słowa i zwroty, które w identycznym znaczeniu pojawiły się we wszystkich trzech źródłach. Materiał analizowany składa się z ok. 40 słów i zwrotów; nie jest podawany w kontekście użycia, a tylko w zestawieniu obrazującym zjawiska, o których mowa w artykule. 
wartości „bądź na zasadzie empirycznej, podobnie jak wszelkich innych przedmiotów, bądź - wobec niesprowadzalności dobra i zła do żadnych cech opisowych - za pomocą szczególnej władzy umysłu, jaką stanowi intuicja" [Puzynina 1992: 22]. $\mathrm{Z}$ prezentowaną $\mathrm{w}$ tym artykule filozofią wiąże się w sposób ścisły relatywistyczne podejście ontologiczne, które łączy świat wartości z podmiotami poznającymi [Puzynina 1992: 22-24], wykluczając wartości z definicji znaczenia leksemu.

Inspiracją do badań nad relacją słownika gwary młodzieżowej z systemem aksjo-normatywnym była obserwacja zjawiska płynnego przechodzenia jednych nazw określających czynności w drugie, przy zachowaniu wagi wartości lub postawy określanej danymi nazwami. Za każdym razem status ontyczny odbieranej wartości nie zmieniał się, zmieniały się jednak określenia lub konotacje, które odnosiły się bezpośrednio do wartości. Można stwierdzić, że wartości uznawane przez społeczność, grupę czy też klasę społeczną, wreszcie całe społeczeństwo nie podlegają takiej zmianie jak sam język, którego dana społeczność używa, by określić pożądane i niepożądane postawy, zachowania lub czyny. Zmiany na poziomie językowym, zwłaszcza w gwarach i socjolektach, wynikają poniekąd z własności specyficznego języka, jakim porozumiewa się dana grupa. Leksemy używane w środowisku młodzieży podlegają zjawiskom mody językowej i ekonomizacji języka, są silnie kształtowane przez czynnik kulturowy i podporządkowane indywidualnemu użyciu.

Idąc śladem wskazanych koncepcji ideologicznych, kategorią, która koresponduje ściśle z opisem systemu aksjo-normatywnego młodzieży, jest kategoria punktu widzenia, zaczerpnięta z dorobku Jerzego Bartmińskiego. Badacz wywodzący się ze szkoły lubelskiej [Bartmiński 1990: 112] definiuje punkt widzenia jako:

czynnik podmiotowo-kulturowy, decydujący o sposobie mówienia o przedmiocie, w tym m.in. o kategoryzacji przedmiotu, o wyborze podstawy onomazjologicznej przy tworzeniu jego nazwy, o wyborze cech, które są o przedmiocie orzekane w konkretnych wypowiedziach i utrwalone w znaczeniu. Przyjęty przez podmiot mówiący jakiś punkt widzenia funkcjonuje więc jako zespół dyrektyw kształtujących treść i strukturę treści słów i całych wypowiedzi, dających też podstawę do identyfikacji gatunków mowy i stylów językowych.

Elementy, które wydają się najściślej odpowiadać aksjologii kognitywnej i subiektywizmowi to specyficznie ujęty: „czynnik podmiotowo-kulturowy” i „,echy, które są o przedmiocie orzekane i utrwalone w znaczeniu”. Wskazują one także na nierozerwalny związek postrzegania - w tym przypadku wartości, i orzekania o przedmiocie poznania. Zachodzi tu nierozerwalna relacja, której efekt, czyli określone postrzeganie wartości, jest ściśle uzależniony od punktu widzenia. W przypadku pojęć tak ogólnych jak wartości, postawy czy wzorce moralne mamy do czynienia z punktem widzenia skonwencjonalizowanym, a więc nie jednostkowym, będącym wypadkową rozwoju kulturalnego, moralnego i duchowego danej społeczności, kultury czy cywilizacji. Punkt widzenia może być jednak zindywidualizowany na poziomie grupy, co znaczy, że może w obrębie jednej 
grupy stanowić wyraz postrzegania odmiennego niż percepcja całej społeczności.

Koncentrując się na językoznawczej perspektywie badań relacji leksykonu i systemu aksjo-normatywnego, przywołać należy podział wartości zastosowany przez Jadwigę Puzyninę w pracy Jak pracować nad językiem wartości? [Puzynina 1991: 136]. Badaczka wprowadza rozróżnienie ściśle aksjologicznego, filozoficznego rozumienia wartości jako „tego, co określa dobre lub złe” i jej rozumienia potocznego, funkcjonującego w publicznym dyskursie. Potoczne rozumienie wartości sprowadzić można do wskazania na to, co dobre i godne naśladowania (odrzucana jest tu zatem binarność wartości, a jej powszechne rozumienie przenosi ciężar na interpretację pozytywną, to główne zróżnicowanie dotyczące filozoficznego i potocznego zróżnicowania konceptualizacji wartości, ukazane między innymi w pracach Tatarkiewicza $i$ in.). Tak rozumiana wartość da się sprowadzić do ukazanej eksplikacji [Puzynina 1991: 130-131]:

$X$ jest ważne - 'X jest czymś, z czym wiążą się fakty, wydarzenia lub stany rzeczy stanowiące według nadawcy jakieś wartości pozytywne i/lub negatywne. Nadawca uważa z tego względu X za warte uwagi'.

Czerpiąc z dorobku Tatarkiewicza, badaczka wskazuje na istnienie tych cech, stanów i czynności, którym - jawiącym się jako nieobojętne dla człowieka przypisać można podstawowe pozytywne walory. Takimi wartościami pozostają te określane jako transcendentne (sacrum) i nietranscendentne, czyli poznawcze, estetyczne, moralne, witalne i odczuciowe (hedonistyczne) [Puzynina1991: 132133]. Przy czym należy zaznaczyć, że w badaniach nad slangiem młodzieżowym konieczne - i jako takie prezentowane w niniejszej pracy - było scalenie podobnych wartości we wspólne kategorie, co zostanie pokazane przy zestawieniu wyrażeń wartościujących z języka gwary młodzieżowej. Jakkolwiek można (przy wielu ograniczeniach) zgodzić się z tezą, że wartościowanie stanowi lub może stanowić definicyjny element wyrazu, przyglądając się dyskusji racjonalistów i irracjonalistów, stwierdzić można, że o wiele pewniejszym sformułowaniem jest teza o wartości nadawanej wyrazom dopiero przez środowisko użytkowników i kontekst używania wyrazów w komunikacji.

Posługując się typologią wypracowaną na gruncie filozofii, modyfikując nieco podział dokonany przez Puzyninę, należy przedstawić typologię wartości wyrażanych przy pomocy środków językowych.

Przedstawiona w pracy kategoria punktu widzenia przekłada się na postrzeganie możliwości opisu wartości, a co za tym idzie ich percepcję. Punkt widzenia nie jest zatem istotny tylko w przypadku użytkowników języka w badanej sytuacji komunikacyjnej, ale i w przypadku badaczy. Puzynina, a za nią i Adrian Kuźniar [Kuźniar 2009: 25], stwierdza, że wartościowanie może być elementem definicyjnym wyrazu. Dzieje się tak wtedy, kiedy rdzeniowi znaczeniowemu można jednoznacznie przypisać określoną wartość. 
Jak już zostało wcześniej wspomniane, system języka nie jest jedynym narzędziem dostosowanym do przekazywania i opisu wartości. Dla porządku należy przybliżyć specyfikę typologii narzędzi służących nazywaniom wartości.

Występowanie semów wartości w obrębie podstawowej wartości wyrazu

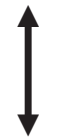

Obecność składnika znaczeniowego wartościującego całą treść

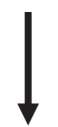

Konotacja ustabilizowana poprzez użycie

Rys. 1.1. Językowe i pozajęzykowe środki wyrażania wartości

Źródło: opracowanie własne na podstawie Puzynina 1991: 130-131

Stosując najbardziej intuicyjną typologię, rozróżnić można następujące grupy wartości:

\begin{tabular}{|c|c|}
\hline & Туру wartos \\
\hline poznawcze & $\begin{array}{l}\text { A potem ci się komputer wyłączył? } \\
\text { badaj, guglaj, obcinaj } \\
\text { za sałatą } \\
\text { hejter } \\
\text { podkręcić }\end{array}$ \\
\hline witalne & $\begin{array}{l}\text { YOLO } \\
\text { bajabongo } \\
\text { Bieda } \\
\text { biżu } \\
\text { blejzer } \\
\text { Za znajomych to masz Virtuti Militari } \\
\text { laps } \\
\text { ogarniać } \\
\text { fristajlowá́/fristajl } \\
\text { odpimpować } \\
\text { pocisnąć/pocisk } \\
\text { podłączyć się }\end{array}$ \\
\hline estetyczne & $\begin{array}{l}\text { SWAG } \\
\text { fladra } \\
\text { lachomat } \\
\text { lambadziara } \\
\text { obrandować/obrandowany } \\
\text { oczojebny/oczojebisty }\end{array}$ \\
\hline moralne & $\begin{array}{l}\text { churching (analogicznie do clubbing) } \\
\text { sprzedać liścia/plombę } \\
\text { trzymać fason }\end{array}$ \\
\hline
\end{tabular}

Rys. 1.2. Relacja procesów konotowania i wartościowania

Źródło: opracowanie własne na podstawie Puzynina 1991: 128 
Zróżnicowanie procesów wartościowania i konotowania oddaje przedstawiony rysunek 1.2. Zaprezentowane na rysunku wartościowanie i konotowanie pozostają wobec siebie w częściowej opozycji. Przy procesie konotowania wartości należy ponadto zdawać sobie sprawę z nierównomiernej recepcji postaw, wzorców i wartości przez poszczególnych członków grupy. Stąd też w aksjologii wprowadza się podział wartości ze względu na procesy percepcyjne [Pelc 1970: 185].

Przypomnieć należy, że w środowiskach i grupach społecznych występuje zjawisko intuicyjnego pojmowania zjawisk i postaw jako wartości, wskazywane w pracach Sztompki, Ossowskiej i in. Dążenie do osiągnięcia najwyższych wartości jest równocześnie dążeniem do odwzorowania najbardziej pożądanej postawy. Aksjolodzy wyróżniają ponadto wartości odczuwane, deklarowane i uznawane. Naśladowanie postaw przez młodzież dotyczyłoby zatem wszystkich tych grup wartości.

Wartości te są waloryzowane pozytywnie i negatywnie (określane jako „hardkorowe”), co stoi w kontraście z wyrażeniami występującymi jako neutralne (identyfikowane jako „casualowe”). Ich poprawne wartościowanie uzależnione jest od kontekstu, w jakim zostają użyte. I tak obok neutralnego PRACOWAĆ, ROBIĆ występuje ambiwalentne ZAHARATAĆ, które przybiera znaczenie „,nieludzko zmęczyć się, upodlić”, ale też „wykonać kawał solidnej pracy”, obok NEUTRALA, SZARAKA oznaczającego „zwyczajną, niewyróżniającą się osobę", istnieją określenia FRIK I GEEK, które różnią się od siebie w niewielkim stopniu. Pierwsze oznacza „kompletnego świra”, ale i „zapaleńca, amatora czegoś”. W przypadku GEEKA ,amatora informatyki”. GEEK oznaczać może ponadto osobę wykluczoną przez grupę. Ambiwalentne jest również znaczenie leksemu RZEŹNICZYĆ, który może być rozumiany jako „przodować w jakiejś dziedzinie, znajdować się na pierwszym miejscu”, ale i „zachowywać się nieodpowiedzialnie". Z kolei wyrażeniu (JEST) LAJTOWO, LAJTOWY oznaczającemu stan normalny przeciwstawić można leksem ODJECHANY, który oznaczać może wartości skrajnie pozytywne oraz skrajnie negatywne. ODJECHANY może być pomysł, człowiek, mebel, zwierzę, sytuacja, impreza. Wystarczy, że spełni kryterium wyróżniania się ze swojej grupy dzięki szczególnym właściwościom. Synonimiczne w pewnym sensie ODLOT i ODJAZD funkcjonują w gwarze podobnie jak ODJECHANY, wskazując na sytuacje skrajne, nie wykazują jednak takiej łączliwości jak leksem ODJECHANY. Tej grupie leksemów przeciwstawić można neutralny HOMING lub HOŁMING (choć sam leksem DOM kulturowo konotowany jest częściej pozytywnie niż neutralnie lub negatywnie), oznaczający „spędzanie czasu w domu, wynikające z wyboru, a nie konieczności”. Neutralnym leksemom UCZEŃ i NAUKA przeciwstawiane są leksemy GIMBUS i GIMBAZA. Te ostatnie są wartościowane negatywnie przez osoby nieuczące się w gimnazjum i oznaczają „osobę niepoważną, dziecinną, głupią" i „naukę niepoważną, stan niewiedzy". Z kolei przez uczniów gimnazjum leksemy te wartościowane 
są pozytywnie, jako włączające $\mathrm{w}$ struktury grupy i utożsamiające z nią. Ciekawym zjawiskiem jest powstanie leksemu CEBULAK i przeciwstawienie go leksemowi SWETRZAK. CEBULAK oznacza „osobę nie umiejącą zachować się w towarzystwie, nieobytą, mentalnie pochodzącą ze wsi" i wywodzi się od CEBULI oznaczającej ,dziurawe skarpety - wyraz zaniedbanego wyglądu i nieumiejętności dostosowania się do wymogów panujących w danym towarzystwie". Od leksemu CEBULA utworzony został leksem CEBULAK, przez analogię do jednostki SWETRZAK, która z kolei oznacza „osobę porządną, umiejącą zachować się w towarzystwie, nie biorącą udziału w imprezach, schludną i zadbaną". Określenie cebulak zyskuje popularność w Internecie, przybierając formę wyrażenia „Polaki - cebulaki” lub „dziwaki - cebulaki”.

Podsumowując, podział na neutralne i nacechowane pozytywnie lub negatywnie w słowniku gwary młodzieżowej oddaje typologia zjawisk „casualowych”, a więc zwyczajowych/domowych i „hardkorowych”, czyli takich, którym można przypisać ocenę ambiwalentną. Należy przy tym zauważyć, że zjawiska neutralne są podawane w opozycji do ambiwalentnych, czyli tych pożądanych i powielanych, ponieważ wyróżniających się z tła lub też potępianych przez grupę i występujących w kontekście wyrażeń jako przykłady zachowań negatywnych.

Równie interesującym zjawiskiem wydaje się być występowanie w języku określonych typów wartości, podzielonych w niniejszej pracy na cztery kategorie $^{2}$ : poznawcze, witalne, estetyczne i moralne. Grupując powyższe wartości w określone kategorie, unika się próby tworzenia hierarchii wartości, a jedynie postuluje się stworzenie danych typów przez podobieństwo do prototypów postulowanych postaw.

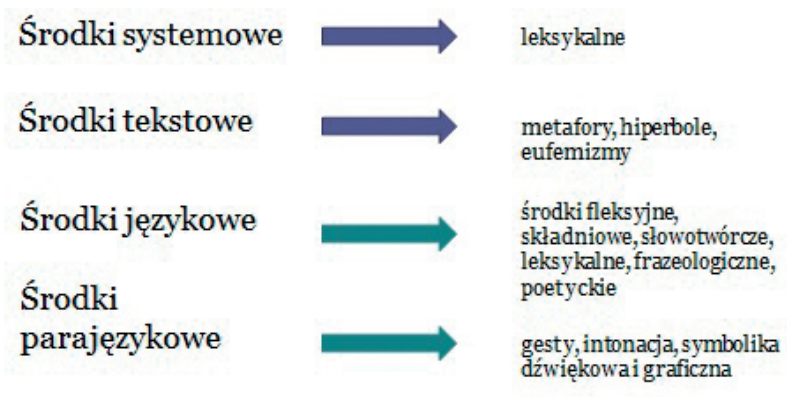

Rys. 1.3. Typy wartości i ich elementy

Źródło: opracowanie własne

\footnotetext{
${ }^{2}$ Zmodyfikowane kategorie nietranscendentne, występujące u Tatarkiewicza i Puzyniny, sprowadzone do typów: estetycznego, moralnego, poznawczego, witalnego oraz odczuciowego lub hedonistycznego [Puzynina 1991: 136].
} 
Pierwsza kategoria gromadzi te wyrażenia, które mogą być interpretowane w zakresie wyrażania wartości poznawczych. BADAĆ, GOOGLAĆ, OBCINAĆ oznacza „sprawdzać coś, weryfikować, szukać”, kulturowo jest konotowane dodatnio. Wyrażenie „A potem ci się komputer wyłączył?” oznaczać może niedowierzanie wygłoszonemu poglądowi albo napiętnowanie niesprawdzonej, nierzetelnej informacji. Jedynie leksem HEJTER, pochodzący od HATE (NIENAWIŚĆ), zawiera w sobie sem wartościowany negatywnie. Pozostałe przykłady pochodzące $\mathrm{z}$ tej grupy są uwarunkowane asocjacyjnie. Przeważa tu dążenie do rzetelnego i pełnego poznania oraz przyrostu wiedzy. Jako niepożądane wskazywane są: ignorancja, niekonstruktywna negacja i niewiedza.

Kolejną kategorią wprowadzoną w niniejszej pracy jest typ wartości witalnych, w których dominuje podkreślenie konieczności korzystania z życia i celebrowania każdej chwili, czego przykładem mogą być określenia YOLO (you only live once), BAJABONGO oznaczające „pochwałę dla czynu, który wydarzył się lub ma się wydarzyć; czerpanie korzyści z aktualnej sytuacji”, ale też „wydarzenie negatywne, destrukcja czegoś lub uszkodzenie kogoś”. Z kolei leksem FRISTAJLOWAĆ oznacza „posługiwać się dostępnymi środkami, działać spontanicznie, pozytywnie" i używany jest w kontekście podobnym do ODPIMPOWAĆ (,zrobić coś nieoczekiwanego i szalonego, cieszącego się uznaniem”) i POCISNĄĆ („działać spontanicznie, zręcznie zripostować, wzbudzić śmiech”). Pozytywnie wartościowane są leksemy BLEJZER (,pozer, szpaner, osoba podążająca za modą”) i BIŻU (,osoba modna, ubrana estetycznie, błyszcząco, kolorowo). Negatywnie z kolei oceniane są leksemy BIEDA (pochodzący od nazwy sieci sklepów i oznaczający sklepy dyskontowe w ogóle), PODŁĄCZYĆ SIĘ („korzystać z cudzych dóbr, żerować na kimś”) oraz wyrażenie „Za znajomych to masz Virtuti Militari” (oznaczające niesympatycznych, źle dobranych znajomych). W powyższej grupie ukazana jest chęć korzystania z życia, wybierania stylu życia opartego na konsumpcjonizmie, potępianie biedy i przebywania w niemodnym, spokojnym towarzystwie.

Wartości estetyczne wskazują przede wszystkim na promowanie wyglądu zewnętrznego oraz dokonywanie oceny człowieka przez ocenę tego, jak wygląda. Świadczy o tym konotowana oceniająco wartość wyrażenia SWAG (oceniająca walory estetyczne wyglądu, modne ubranie i odpowiednie do stroju zachowanie, szykowność i klasę), podobnie OBRANDOWANY (wyrażenie pochlebne o osobie noszącej ubrania znanych i popularnych marek lub deprecjonujące o osobie, która eksponuje metki marek niemodnych lub uchodzących za tanie). W grupie tej widać negatywny stosunek do ludzi, którzy chcą naśladować bogaty styl życia, robiąc to nieudolnie (LAMBADZIARA, FLĄDRA, BAJERANT mają wspólny mianownik w postaci ,tandetnego, niewłaściwego wyglądu, nieudolnie naśladującego trendy wyznaczane przez modę”) lub nachalnie (LACHOMAT, czyli „osoba wyglądająca nieestetycznie, o nadmiernej opaleniźnie i nieudolnym makijażu). 
Wartości moralne jako ostatnia grupa, wytypowana w wyrażeniach z gwary młodzieżowej, koncentruje się niejako wokół wspomnianego spontanicznego stylu życia, zawierając ponadto pochwałę elastyczności i selektywności wyboru elementów. Wyraża się to chociażby w używaniu leksemów CHURCHING (analogicznie do CLUBBING oznacza „odwiedzanie kościołów w poszukiwaniu nabożeństwa, które odpowiada jednostce formą i treścią”) czy wyrażeń typu „trzymać fason”, co oznacza „wstrzemięźliwość w okazywaniu emocji”. Wartości moralne są najtrudniejsze do wskazania, stanowią bowiem najbardziej płynną i synkretyczną grupę w przypadku grup młodzieżowych.

Badając znaczenie leksemu POZYTYWNIE w grupie młodzieży, zauważyć można zjawisko przesunięcia semantycznego. Występują one w słowniku slangu młodzieżowego.

U Puzyniny, przywołującej definicję za Zeno Vendlerem, POZYTYWNY nie może zastępować DOBREGO, na przykład w znaczeniu: życzliwy, chętnie pomagający innym, zdolny, udany, mający cechy ważne z punktu widzenia użyteczności. W pracy Język wartości [1992: 46-60] badaczka podkreśla, że określenia pozytywny i negatywny dotyczą, jak się wydaje, cech, postaw, działań szczególnie ważnych dla życia społecznego (moralnych, intelektualnych, umiejętnościowo-sprawnościowych). Określenie pozytywny nie łączy się z nazwami cech estetycznych, sposobem wykonania czynności oraz wytworem czynności ludzkich. Tymczasem jego współczesne użycie przedstawia łączliwość z innymi kategoriami. POZYTYWNY rozumiane być może jako: DOBRY, RACZEJ DOBRY, UMIARKOWANIE DOBRY, ale: POZYTYWNIE = BARDZO DOBRZE, ŚWIETNIE, WSPANIALE. Pozytywne może być: spotkanie, odczucia względem innej osoby, wiadomość i reakcja na wiadomość. Pozytywnymi można określać kolory i przedmioty, choć nie wszystkie. Pozytywne nie będą zatem schody, ławka w parku, albo krzesło, choć sama droga do szkoły, park lub okulary mogą być określane jako pozytywne w niemetaforycznym znaczeniu. POZYTYWNIE stanowi opozycję do ŚREDNIO, ŹLE, OKROPNIE.

Przykładowe użycie:

A: Jak minął dzień?

B: Pozytywnie.

\section{A: Jak matma na maturze? \\ B: Pozytywnie.}

W gwarze młodzieżowej funkcjonuje ponadto wyrażenie „pozytywna rysa”. Określeniem tym nazywa się kogoś, kogo się lubi; osobę, która przypadła nam do gustu.

Język, którym posługuje się młodzież to język asocjacji uwarunkowanych kulturowo. Językiem tym określane są codzienne sytuacje, komentarze postaw i przekonań, tworzone ad hoc oceny sytuacji. Język ten funkcjonuje w szkołach, 
na forach internetowych czy w popularnych memach. Często pozostaje niezrozumiały dla osób niebędących członkami grupy, która go używa. Jego zadaniem jest dopasowanie się do nowych sytuacji, do wydarzeń bieżących, do uniwersalnych postaw. W jego strukturze widoczne są silne wpływy języka angielskiego.

Język określa wartości poprzez kontekst i asocjacje. Trudno jednoznacznie orzec (poza nielicznymi wyjątkami), że język ten jest nośnikiem wartości zapisanych immanentnie w jego strukturze. Postrzeganie wartości w obrębie grupy zdaje się być uzależnione od indywidualnego lub zindywidualizowanego na poziomie grupy właśnie punktu widzenia. Wartości dające się wyrazić przy pomocy aktualnie określających je słów lub wyrażeń (wyrażane poprzez sem stanowiący główny rdzeń interpretacji wyrażenia) występują w leksykonie zaczerpniętym ze slangu młodzieżowego rzadziej niż wyrażenia dotykające zagadnienia wartości poprzez zastosowanie konotacji. Można zaryzykować stwierdzenie, że określanie wartości przez kontekst kulturowy i wiedzę pozajęzykową, nie zaś przez definicję wyrażeń, dotyczy języka w ogóle. Znaczenie bowiem tkwi poza językiem, nie w nim.

Zasadnym wydaje się być prowadzenie dalszych badań nad aksjo-normatywnym wymiarem slangu młodzieżowego i relacją słownika slangu do postaw i wartości preferowanych przez daną grupę, w tym przypadku młodzież, zwłaszcza w kierunku kształtowania postrzegania wartości przez pryzmat słów, jakie je określają.

\section{Bibliografia}

Bakuła K. [2005], W stanach dalekich od równowagi: mowa i punkty widzenia, [w:] J. Bartmiński (red.), Punkt widzenia $w$ tekście $i w$ dyskursie, Lublin.

Bartmiński J. [1990], Punkt widzenia, perspektywa, językowy obraz świata, [w:] J. Bartmiński (red.), Językowy obraz świata, Lublin.

Kajtoch K., Kajtoch W. [2010], O osobliwym postugiwaniu się słowem w czasopismach młodzieżowych $i$ w czasopismach subkultur, [w:] A. Pajdzińska, R. Tokarski (red.), Relatywizm w języku $i$ kulturze, Lublin.

Kuźniar A. [2009], Język i wartości. Racjonalność akceptacji ekspresywizmu metaetycznego, Wydawnictwo Naukowe Semper, Warszawa.

Lakoff G., Johnson M. [2010], Metafory w naszym życiu, Aletheia, Warszawa.

Miejski słownik slangu i mowy potocznej, www.miejski.pl

Pelc J. [1970], Znaczenie jako narzędzie, Studia Semiotyczne I, s. 172-190.

Puzynina J. [1992], Język wartości, Wydawnictwo Naukowe PWN, Warszawa.

Puzynina J. [1991], Jak pracować nad językiem wartości?, [w:] J. Bartmiński (red.), Język a kultura, Wrocław.

Puzynina J. [1982], Językoznawstwo a aksjologia, „Biuletyn Polskiego Towarzystwa Językoznawczego", zesz. 32, s. 23-32.

Stownik slangu, neologizmów i mowy potocznej, www.vasisdas.pl. 
Tokarski R. [2010], Relatywizm w języku - relatywizm w tekście, [w:] A. Pajdzińska, R. Tokarski (red.), Relatywizm w języku i kulturze, Lublin.

Tylor J. R. [2001], Kategoryzacja w języku. Prototypy w teorii językoznawczej, Kraków.

Wierzbicka-Piotrowska E. [2010], Zwrot porozmawiajmy ,jak Polak z Polakiem" przykładem uświadomionego relatywizmu konwersacyjnego, [w:] A. Pajdzińska, R. Tokarski (red.), Relatywizm w języku i kulturze, Lublin.

Zaron Z. [1985], Wybrane pojęcia w analizie semantycznej (Kochaj bliźniego swego), Zakład Narodowy im. Ossolińskich Wydawnictwo Polskiej Akademii Nauk, Wrocław. 